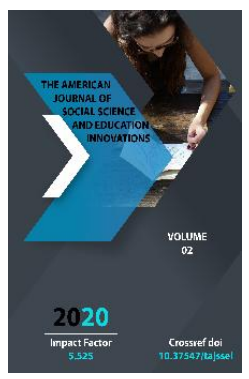

\title{
Translation As A Fifth Speech Activity
}

\author{
Nasir Mansurovich Kambarov \\ Candidate of Philological Sciences, Professor, English Translation Theory and Practice \\ Department, Uzbekistan State University of World Languages, Tashkent, Uzbekistan
}

Journal Website:

http://usajournalshub.c

om/index,php/tajssei

Copyright: Original

content from this work

may be used under the

terms of the creative

commons attributes

4.0 licence.

\section{ABSTRACT}

The present article deals with translation to be the fifth activity in addition to speaking, writing, listening and reading. It dwells upon it not as a type of exercise which is widely used in teaching a foreign language but as a separate type of activity. The main attention is also paid to different viewpoints on the matter and the author made an attempt to prove that the translation can be used both as a skill and a type of activity requiring special competence for mastering it as a specialty. Translation, being an independent science, has its own methods, ways, rules and important competences which are in its domain.

\section{KEYWORDS}

Translation; skill, competence; activity; a foreign language; (written) translation; interpretation; subskills; approaches; viewpoints;

\section{INTRODUCTION}

The Training translators is closely connected with teaching a foreign language as the it proceeds the second one. The important thing is to train important skills. Namely they differ when it comes to skills. For one to be a teacher student will have to learn those four basic skills integrating them. When training translators along with those four basic skills an additional skill of translating and/or an interpreting is taught. Training a translator focuses on the written skill. Additional skill which is necessary for a translator is both reading and listening comprehension. As for an interpreter he will need listening and speaking skills first.

\section{MAIN PART}


Teaching any subject, first of all, should be directed at training certain skills mastered. Translation is an independent science which has also its skills to be trained. But in teaching a foreign language translation, in most cases, is considered as a type of exercise to train specialists in foreign language or teachers of foreign languages.

In recent years, translation activity has been widely used as a process as well as a fifth skill. It is explained by a number of factors. First, a person who knows a foreign language is obliged to have translation/interpretation skills and qualifications, regardless of the activity $\mathrm{s} / \mathrm{he}$ performs and uses them (its written and oral form) in her/his daily life; secondly, An English teacher needs it as a type of exercise, but also in the process of training the skills that must be applied directly in implementing to the activity, thirdly, a translator must have skills and sub-skills that $\mathrm{s} /$ he always uses in her/his work.

Translation in general is a skill that includes reading, writing, listening (comprehension) and speaking. Until now, in the literature on methodology, translation has been viewed, as mentioned above, as a type of exercise in the narrow sense in teaching a foreign language, for instance, Russian scholar M.V. Konysheva (2016) in her article Translation as a Means of Learning a Foreign Language expressed her certain view on this issue. However, translation is a special skill and is taught specifically as it is taught to write or to speak. In teaching foreign languages, and in studying any language in general, translation must be understood in broad sense, not in a narrow sense.

The existing literature in translation studies contains different views, understanding and approaches on the types of translation. Some scholars refer to the translation only as written and oral, while others acknowledge that translation and interpretation are divided into several sub-competence types in the addition to translation and interpretation skills. But we think that we can add two more important sub-skills as analyzing and editing. A person or a specialist who knows a foreign language and has no knowledge in translation may have writing, speaking, listening and reading skills but may not have (and it is undoubtedly so) translation skills. The following information on translation skills can be found at https://www.pactranz.com/thetranslator-skillset. According to the mentioned site there exists seven competency core skills and they are as follows:

1. Advanced language knowledge.

2. Excellent writing skills.

3. In-depth cultural knowledge.

4. Sound research skills.

5. Best practice translation and review processes.

6. Sound translation judgment.

7. Computing and CAT skills.

Here we see that the notion translation skill is considered broader. Among skills here we can distinguish only three of them, including writing, research and computing and CAT skills (See: https://www.pactranz.com/thetranslator-skillset ). One can notice the mixture of skills, sub-skills, competences and in some cases translator's abilities..

We think the notion advanced language knowledge itself includes reading, writing, and listening and speaking skills and the rest are knowledge, judgement and process.

In the process of learning a language translation is a part of it, along with a writing skill and if it is interpreting and speaking skills trained. An Uzbek scholar J. Jalolov (1996) called translation a sub-skill. In the process of language teaching, translation skill, which is the fifth one of the four basic skills, is treated as an inactive type, if to tell more precisely a type of exercise, in comparison with others. The teaching of translation skills as a type of 
exercise differs from the skills that are used in the special training of translators (see Jalolov, 1996). The philologist will not have the skills of translation, but in the process of studying a foreign language, the skills will be taught on the integrated basis.

The above-mentioned types of translations refer to the process carried out according to the purpose of the activity and indicate the degree of necessity of that skill for him/her. It is considered important for an interpreter in addition to writing, speaking, listening and reading. A. Zimnyaya (1981) stated the fact that translation existed as a fifth type of speech activity in the 80 -ies.

In order to be a translator and/or an interpreter for a specialist with four basic skills of a foreign language, it is necessary to master the fifth speech activity - translation. A foreign language specialist or expert who has no special training in the field or without qualification of a translator and/or an interpreter cannot be a professional translator. One should stress here one thing if a language expert is genius, i.e. s/he is gifted and that gift was granted by God then s/he is a translation and/or an interpreter. This is an exception rather than a widespread phenomenon.

One more important thing should be underlined here. The term "translation" is also used in two senses: narrow and broad. The first one means general translation and the second one - written translation. And there is one more term which is "interpretation" which deals with oral form of translation. In English these two terms are differentiated, but in Uzbek one and the same notion "tarjima" is used for both forms of translation. And to differentiate them, attributes "og'zaki" and "yozma" are used. According to W.M.Rivers and M.S. Temperley (1978:327$328)$, “... in the system of teaching foreign languages, translation can be viewed from two points of view: as an object of educational and pedagogical activity and specialized (special) learning. It is a special object of translation, therefore, approach as a separate professional activity ... professional translator training in the field of methodology allows us to" guard against the issues and tasks set before us.

Another specialist in translation A. Pinar (2017:3-4) in his doctoral thesis writes: "Only recently have there been strong voices to bring the issue back under discussion in institutional settings. A growing number of researchers has begun to work on the use of translation in foreign-language teaching (Duff 1989; Stern 1992; Widdowson, 2003; House 2009; Cook 2010; Pym et al. 2013). For many years, language researchers and experts imposed the striking idea of L2-dominant classrooms with a strong emphasis on excluding translation and avoiding L1 use. They came up with a variety of reasons for their claim, with almost no empirical justification for their arguments; they failed to give any scientific evidence for the detrimental effect of translation on and during the process of foreign-language learning. Carreres (2006: 1) summarizes the current situation in the field as follows: "much valuable work has been done in the past decade in the field of translation pedagogy, but we still lack a strong empirical foundation on which to base our practice". The present information and detailed research proves that translation is still means of teaching a foreign language and a type of exercise.

But now it is time to concentrate our attention on translation as a specialty with its skills, techniques and competences. It goes without saying that skills of translation and interpretation differs from each other.

There is also a difference between the skills of translation and oral interpretation specialists, which is considered the type of translation 
Doi: https://doi.org/10.37547/tajssei/Volume02Issue08-65

activity. Although there are general aspects of translation with interpretation, it is possible to observe certain differences in them. For example, Canadian translatologist Brain Harris (2016:11) has shown that there are the following differences in the activities of interpreters and translators (see Visson, 2017, 11)):

\begin{tabular}{|c|c|}
\hline Translation & Interpretation \\
\hline $\begin{array}{l}\text { 1. In translation, the text is delayed, that is, } \\
\text { it is created until the translation begins. }\end{array}$ & $\begin{array}{l}\text { 1. It is created just on the spot and at the } \\
\text { present time. }\end{array}$ \\
\hline $\begin{array}{l}\text { 2. The text is finished and no changes are } \\
\text { made. }\end{array}$ & $\begin{array}{l}\text { 2. The idea is incomplete, and in the process } \\
\text { of creation, it is impossible to predict what } \\
\text { it will end with. }\end{array}$ \\
\hline $\begin{array}{l}\text { 3. Reading the text, putting aside a certain } \\
\text { period of time, it is possible to return to it } \\
\text { later. }\end{array}$ & $\begin{array}{l}\text { 3. The verbal message "disappears" quickly, } \\
\text { the translator can only rely on his/her } \\
\text { memory. }\end{array}$ \\
\hline $\begin{array}{l}\text { 4. The text can consist only of a material } \\
\text { consisting of words (that is, there is no } \\
\text { hand or face movement in it - L.V.). The } \\
\text { translator does not know under what } \\
\text { circumstances it is written. }\end{array}$ & $\begin{array}{l}\text { 4. Thoughts are expressed by gestures, the } \\
\text { translator sees directly in what conditions } \\
\text { the message is created and the speaker's } \\
\text { output. }\end{array}$ \\
\hline $\begin{array}{l}\text { 5. Most texts are the product of a single } \\
\text { author's work. The translator will have }\end{array}$ & $\begin{array}{l}\text { 5. In interpretation, the interpreter } \\
\text { translates one or more entirely different }\end{array}$ \\
\hline
\end{tabular}




\begin{tabular}{|l|l|}
\hline enough time to get used to his style. & speaking style. \\
\hline $\begin{array}{l}\text { 6. Since the text is written before, it does } \\
\text { not have a direct strong emotional impact } \\
\text { on the translator. }\end{array}$ & $\begin{array}{l}\text { 6. The interpreter knows only the harsh } \\
\text { environment of the meeting; s/he } \\
\text { her/himself is influenced by the } \\
\text { environment. }\end{array}$ \\
\hline $\begin{array}{l}\text { 7. Before printing, the translator can } \\
\text { reproduce the text and edit the scan from } \\
\text { beginning to end. }\end{array}$ & $\begin{array}{l}\text { 7. The interpreter must translate correctly } \\
\text { from the very beginning. S/he will not be } \\
\text { given another chance. }\end{array}$ \\
\hline $\begin{array}{l}\text { 8. The translator also does not know who is } \\
\text { his/her recipient, like the author. There is } \\
\text { no direct connection between the author } \\
\text { and the reader. }\end{array}$ & $\begin{array}{l}\text { 8. The interpreter knows his/her audience, } \\
\text { more precisely s/he sees it. }\end{array}$ \\
\hline
\end{tabular}

In showing the differences between the above written and oral translation the author sees that it attaches more importance to the extralinguistic aspect than linguistic.

In our study, we believe that it will be expedient to use the term competency rather than the term skill. Different scholars use various names for the term skill, for example, art of translation ( $\mathrm{G}^{\prime}$. Salomov), translation skills (N. Komilov), and translation qualification. As in general translation, much attention is paid to both interpretation and translation competences. Here translation competence is used in a broad sense. For example, interpretation implies memory and speech related to the competence and the ability to remember a word, a word combination, a sentence, numbers and proper names, and to recreate it in a foreign language or in a native language speech.

Without consecutive interpretation skills, it is impossible to switch to the simultaneous interpretation qualification. The main difference between simultaneous interpretation and consecutive interpretation is the process of taking place of the speech and of the translation. Listening and speaking in terms of importance in interpretation takes the important place in terms of its qualification, while in translation all the qualifications or sub-skill qualifications are in the first place.

Differences between interpretation and translation according to Brayn Harris, included the technical aspect of translation, but not the qualification. We believe that this difference can be presented as follows: 


\begin{tabular}{|c|c|}
\hline \multicolumn{1}{|c|}{ Translation } & Interpretation \\
\hline $\begin{array}{l}\text { Writing skills (correct application of spelling, } \\
\text { punctuation marks in the translated foreign } \\
\text { language) + translation }\end{array}$ & $\begin{array}{c}\text { Interpretation is based on listening, } \\
\text { understanding and speaking skills. }\end{array}$ \\
\hline Reading skills & $\begin{array}{c}\text { Switching from one language into another } \\
\text { Whispering } \\
\text { (Chouchoutage) }\end{array}$ \\
\hline Review processing skills & Consecutive interpretation \\
\hline Research skills & Simultaneous interpretation \\
\hline Translation judgment skills & \\
\hline
\end{tabular}

\section{RESULTS AND DISCUSSIONS}

Thus except four basic skills it will be appropriate to differentiate one more skill and that is translation (both oral and written). In narrow meaning translation is a sub-skill in teaching a foreign language and in training translators the notion translation is used in broad meaning and it is considered as a competence. A skill and competency seems to be similar, but in reality they are not. So we can observe, according to the information presented in the Internet source (https://resources.hrsg.ca/blog/what-s-thedifference-between-skills-and-

competencies) certain differences between skill and competencies can be identified. "Skills are specific learned activities, while competencies "... take "skills" and incorporate them into on-thejob-behaviors. Those behaviors demonstrate the ability to perform the job requirements competently. Skills + Knowledge + Ability = Competencies" (Ibid).

\section{CONCLUSION}

In conclusion, we can say that translation and interpretation being one the basic skill a component of the competence of training translators (interpreters) are widely used in teaching translation. In training translators the mentioned skills and/or competencies are taken into consideration and mastered. And they will be basis for training specialist and further the mastered skills will be upgraded or refreshed at the in-training courses.

Translation exists as a fifth type of activity due to the existence of translating and interpreting skills without which the activity does not take place in any form. First four basic skills are mastered and afterwards additional two more skills translating and interpreting (which is a sub-skill in teaching a foreign language) and which are basic skills in training highly qualified specialists in translation.

\section{REFERENCES}

1. Виссон Л. Синхронный перевод с русского на английский. (Перевод с английского). -Москва: Р.Валент, 2017. $320 \mathrm{C}$.

2. Жалолов Ж.Ж. Чет тил ўқитиш методикаси: Чет тиллар олий ўқув 
юртлари (факультетлари) талабалари учун дарслик. - Т.: Ўқитувчи, 1996. - 368 6.

3. Зимняя, Ирина Алексеевна. Учебное пособие "Психология перевода": (Для высш. курсов переводчиков) / [Сост. И. А. Зимняя, В. И. Ермолович]. - М. : МГПИИЯ, 1981. - 99 с.

4. Конышева М.В.Перевод как средство обучения иностранному языку/

Актуальные проблемы общей теории языка, перевода и методики преподавания иностранных языков // Сборник трудов конференции . 2016. С. 149-152.

5. Таржима санъати: Мақолалар тўплами (Тахрир хайъати: Ғ.Саломов (масъул мухаррир) ва бошқ.; Тўпловчи Т.Жўраев) - Т.: Ғафур Ғулом номидаги Адабиёт ва санъат нашриёти, 1980. 3046.

6. Harris B. The Importance of Natural Translation. Working Paper \#12, 1977. -29 p.

7. Pinar A.(2017). The Role of Translation in Foreign-language Teaching. Doctoral Thesis. - Supervised by Prof. Dr. Anthony Pym. Tarrogona. - $229 \mathrm{p}$.

8. Rivers W.M., Temperley M.S. (1978) A Practical Guide to the Teaching of English as a Second or Foreign Language. - N.Y. P.327-328.

9. https://www.pactranz.com/thetranslator-skillset

10. https://resources.hrsg.ca/blog/what-s-thedifference-between-skills-andcompetencies

\section{TRANSLITERATION OF REFERENCES}

1. Visson, Lynn (2017) Simultaneous Interpreting from Russian into English. (Translation from English). - Moscow: R.Valent, - $320 \mathrm{p}$.
2. Jalolov J.J. Chet til o'qitish metodikasi. Chet tillar oily o'quv yurtlari (fakultetlari) talabalari uchun darslik. - Toshkent: O'qiturchi, 1996. - 368 b. (Jalolov J.J. Teaching a Foreign Langauge. A textbook for the students of the higher educational institutions (departments). Tashkent: O'qituvchi, 1996. - 368 p.).

3. Zımnıara, Irına Alekseevna. Uchebnoe posobıe "Psıhologiiya perevoda": (Dlıa vyssh. kýrsov perevodchıkov) / [Sost. I. A. Zımnıaı, V. I. Ermolovıch]. - M. : MGPIIIa, 1981. - $99 \mathrm{~s}$.

4. Konysheva M.V.Perevod kak sredstvo obucheniya inostrannomu yazyku/

Aktual'nye problemy obshchej teorii yazyka, perevoda i metodiki prepodavaniya inostrannyh yazykov // Sbornik trudov konferencii . 2016. S. 149152.

5. Tarjima san'ati: Maqolalar to'plami (Tahrir hay'ati: G'.Salomov (mas'ul muharrir) va boshq.; To'plovchi T.Jo'raev) - T.: G'afur G'ulom nomidagi Adabiyot va san'at nashriyoti, 1980. - 304 b.

6. Harris B. The Importance of Natural Translation. Working Paper \#12, 1977. - 29 p.

7. Pinar A.(2017). The Role of Translation in Foreign-language Teaching. Doctoral Thesis. - Supervised by Prof. Dr. Anthony Pym. Tarrogona. - 229 p.

8. Rivers W.M., Temperley M.S. (1978) A Practical Guide to the Teaching of English as a Second or Foreign Language. - N.Y. P.327-328.

9. https://www.pactranz.com/thetranslator-skillset

10. https://resources.hrsg.ca/blog/what-s-thedifference-between-skills-andcompetencies 